\title{
Development of Misconception Diagnostic Test in Momentum and Impulse Using Isomorphic Problem
}

\author{
Nadiyah El-Haq Diyanahesa ${ }^{1}$, Sentot Kusairi ${ }^{2}$, Eny Latifah ${ }^{2}$ \\ Physics Education Major, FMIPA, State University of Malang \\ Jl. Semarang No.5 Malang \\ E-mail : ${ }^{1}$ nadiyahesa@gmail.com, ${ }^{2}$ sentot.kusairi.fmipa@um.ac.id
}

Received 1 September 2017, Revised 1 October 2017, Accepted 5 October 2017

\begin{abstract}
Preconception of the students influences to construct knowledge. They entered the classroom with conception formed from daily life. If their conception are not accordance with scientific concepts it's called misconceptions. Misconception is believed by students and used consistently. Teachers need to find out information on a student misconceptions by providing diagnostic tests immedietly. Diagnostic instrument that measure more accurately concepts understanding is isomorphic. Problem isomorphic composed of several question in different context and representation, but solved by the same principles. The goal of this study developing a multiple-choice diagnostic test instrument isomorphic to diagnose misconception of students on momentum and impulse. This study is research and development using ADDIE model (Analysis, Design, Development or Production, Implementation or Delivery and Evaluations). Development steps consist of: (1) Analysis, (2) Design, (3) Develop, and (4) Implement. Before Implement steps, test instrument validated by lecture and two teachers. The instrument have been revised administered to students of class XI MIA 4 MAN Tlogo Blitar and X MIA U1 MAN 1 Tulungagung. Results of this study are 15 items multiple choice diagnostic instruments isomorphic belongs five indicators. Based on the validation by two physics teachers and lecturers, instrument accordance used as a diagnostic instrument capable to distinguish between students misconceptions and naive concept. Around $67.8 \%$ of students who have answered the description are still misconceptions. Based on the test analysis accordance with open ended question instrument test diagnostic isomorphic produce higher accuracy by taking two of the three questions the answers provided.
\end{abstract}

Keywords: isomorphic problem, misconception, momentum and impulse

\section{Introduction}

Assessment is one component that greatly affects the success of learning done by a teacher. Assessments can be utilized by teachers to evaluate the achievement of learning objectives.Assessment results are analyzed to determine student progress and difficulties (Permendikbud Number 66, 2013). Assessment results can also be used by students as self-reflection materials, so that students can obtain better learning outcomes. Assessment activities are influenced by assessment instruments that support 
the improvement of students 'learning ability, support the functioning of students' mind power to the maximum, and make the concept accessible to be better understood by the students. According to Arikunto (2015), the assessment not only measures the achievement of learning objectives, but is also used to make decisions. So in an assessment there is a cognitive theory that says that the context of acquired knowledge and how it is stored in memory has important implications as a signal in a problem that will trigger the reminder of the relevant context (Bransford, et.al, Bjork, et.al, Godden et .al in Singh, 2008). This cognitive theory gives birth to an isomorphic problem assessment instrument in which an assessment instrument comprising of questions is arranged in pairs with different contents, but requires the same concept or principle to solve them.

Student conceptions that are inconsistent with the views of the scientific community are called misconceptions. Misconceptions are believed to be true by students and used consistently (Halloun \& Hesten, 1985). The misconception is not caused by a lack of knowledge, but the understanding of a conception in the wrong way or incomplete (or missing in the wrong way) (Kutluay, 2005). Teachers need to quickly identify misconception information to students by providing diagnostic tests. Diagnostic tests are useful for learning difficulties experienced by students (Treagust, 1988). Diagnostic tests are performed when information is obtained that most students fail to follow the learning process on a particular subject (Suwarto, 2013). Diagnostic tests have become the most effective assessment instrument for identifying misconceptions of students (Arslan, 2012). According to Abdurrahman (2012) without understanding the misconception information in the students will be difficult for teachers to determine the students who have difficulty learning in the end the teacher is also difficult to make the right policy.

The result of interview with physics teacher in MAN 3 Malang, teachers have difficulty in straightening student misconception happened, for example in chapter momentum and impulse, some students experiencing misconception in studying it. This is due to the knowledge and the initial concept that is already embedded in the minds of students. Events experienced by students in everyday life is an experience that made the initial concept for students. Initial concepts that they get while in elementary school, high school, from experience and observation them in the community or in everyday life (Suparno, 2013: 2).

The solution of the problems faced by teachers is a matter of using the instrument granting isomorphic problem for diagnose misconceptions that occur in students. Instruments isomorphic problem can help teachers assess the student's actual ability. Isomorphic problem can also allow teachers in correcting the workmanship matter, because the questions used may include multiple choice questions. So far it has not found any information that revealed the development of type of questions isomorphic problem in matter of momentum and impulse to diagnostic misconceptions students. Based on the above need to do research and development entitled 
"Development of Misconception Diagnostic Test in Momentum and Impulse Using Isomorphic Problem".

\section{Methodology}

The method of research and development of learning media products is using research and development model of ADDIE. Model research and development consists of five phases: Analysis, Design, Development, Implementation, and Evaluation. In the analysis phase conducted a needs analysis and literature, followed by the design stage to make the design of products that will be developed. Further development is done on the development or manufacture products in accordance with the design in the design stage. The next stage is implementation, which at this stage of product testing on a limited basis. The product trial is intended to collect data that can be used as a basis for determining the effectiveness, efficiency and attractiveness of the resulting product. Prior to trials on learners first done expert validation. Validation performed includes the validation of multiple isomorphic choice questions. A limited trial was conducted on 61 students or respondents. Students in the limited trial stage are students who have taken the material momentum and impulse. The experiments were conducted using a description method to examine misconceptions, multiple isomorphic choice questions, and interviews. Based on the results of a limited trial will be conducted evaluation phase, which aims to determine the existing deficiencies as materials to improve products that have been developed. The type of data obtained during the validation process is quantitative data in the questionnaire using Likert scale with 4 categories of choice, where the number 4 means : Very good/ interesting/ feasible/ convenient/appropriate/ right; score 3: good/ interesting/ feasible/ convenient/ appropriate/ right; the 2 means: less good/ interesting/ feasible/ easy/ appropriate/ proper; figure 1 means: very poor/ interesting/ decent/ easy/ appropriate/ appropriate.

\section{Results and Discussion}

\section{Student Error in Problem Solving on Momentum Concept}

Items that are used to show the student's ability to solve problems momentum concepts presented in Figure 1. Problem shows that motorcycles and trucks that each mass of $500 \mathrm{~kg}$ and $1500 \mathrm{~kg}$ moving in the same direction on the highway. At a given moment, the speed of a motorcycle is four times larger than the speed of the truck. At that time, the motorcycle moves by speeding up, while the truck is moving at a constant speed. Students are asked to indicate which of the trucks and motorcycles have greater momentum at the time and are asked to give a reason. A total of 2 students responded that the truck had more momentum than the motorcycle. Students who answered thus have grasped the concept that regardless of the speed of an object, if the mass ofthe object is large, the object always has a greater momentum as well. While 61 other 
students answering correctly on the question, and give reasons to expect that they can solve the problems associated with the concept of the object's momentum depends on the mass and velocity.

\begin{tabular}{|c|c|c|c|c|}
\hline No & Question & $\begin{array}{l}\text { The grouping of students answers } \\
\text { (total } 63 \text { students) }\end{array}$ & $\begin{array}{l}\text { The number } \\
\text { of students }\end{array}$ & Percentage \\
\hline \multirow[t]{4}{*}{2.} & $\begin{array}{l}\text { Motorcycles and trucks each mass } 500 \mathrm{~kg} \text { and } 1500 \mathrm{~kg} \\
\text { moving in the same direction on the highway as } \\
\text { shown below. }\end{array}$ & $\begin{array}{l}\text { 1. Truck, because if an } \\
\text { object has more mass and } \\
\text { that speed is constant or } \\
\text { average then that } \\
\text { momentum also need a } \\
\text { lot. }\end{array}$ & 2 & $3.17 \%$ \\
\hline & $\rightarrow \quad$ Acceleration $=0$ & $\begin{array}{l}\text { 2. Motorcycles, because } \\
\text { although the mass of the } \\
\text { motor is smaller than the } \\
\text { truck, the motor has a } 4 \mathrm{x} \\
\text { speed truck and moves by } \\
\text { speed while the truck is } \\
\text { moving at a constant } \\
\text { speed. }\end{array}$ & 61 & $96.8 \%$ \\
\hline & \multirow[t]{2}{*}{$\begin{array}{l}\text { At any given moment, the speed of a motorcycle is } \\
\text { four times larger than the speed of the truck. At that } \\
\text { time, the motorcycle moves by speeding up, while the } \\
\text { truck is moving at a constant speed. Which one has } \\
\text { greater momentum at that time? Why? }\end{array}$} & & & \\
\hline & & TOTAL STUDENTS & 63 & \\
\hline
\end{tabular}

Figure 1. Those items description to determine the students' ability to compare the momentum an object depending on mass and speed.

On items in Figure 2 are also many students who still do not understand very well the concept of momentum depends on the mass and velocity. That question shows that there is a truck at rest and skates are moving with speed. Students are asked to indicate which of the trucks and rollerboils have greater momentum. A total of eight students who have the conception that the truck has a greater mass will generate even greater momentum against various reasons such as Figure 2 below. Another 55 students responded that roller skates had greater momentum than trucks with a variety of reasons such as Figure 2 below. Thus some students already answered correctly on that question and give reasons to expect that they can solve the problems associated with the concept of the object's momentum depends on the mass and velocity. 


\begin{tabular}{|c|c|c|c|c|}
\hline No & Question & $\begin{array}{l}\text { The grouping of students answers } \\
\text { (total } 63 \text { students) }\end{array}$ & $\begin{array}{l}\text { The number } \\
\text { of students }\end{array}$ & Percentage \\
\hline \multirow[t]{10}{*}{6.} & \multirow{6}{*}{$\begin{array}{l}\text { There is a truck idle and roller } \\
\text { skates are moving at a speed } \mathrm{v} \text { as } \\
\text { shown below. }\end{array}$} & Truck & 8 & $26.7 \%$ \\
\hline & & Roller skates & 55 & $87,3 \%$ \\
\hline & & $\begin{array}{l}\text { 1. Trucks, because the mass of the truck is bigger } \\
\text { than the roller skates. Although the skates move at } \\
\text { speed v but it is not possible the speed of the } \\
\text { skates will equal the mass of the truck }\end{array}$ & 2 & $3.17 \%$ \\
\hline & & $\begin{array}{l}\text { 2. Trucks for truck mass greater than the mass of } \\
\text { roller skates though the truck is at rest, but the } \\
\text { momentum generated bigger trucks }\end{array}$ & 3 & $4.76 \%$ \\
\hline & & $\begin{array}{ll}\text { 3. } & \text { Trucks, because the speed generated on roller } \\
\text { skates will be smaller or less }\end{array}$ & 1 & $1.58 \%$ \\
\hline & & $\begin{array}{l}\text { 4. Truck, because the truck does not move means the } \\
\text { truck does not have the speed and requires a } \\
\text { greater force, so the momentum greater }\end{array}$ & 2 & $3.17 \%$ \\
\hline & \multirow[t]{4}{*}{$\begin{array}{l}\text { Which of the trucks or roller } \\
\text { skates has greater } \\
\text { momentum? Give an explanation! }\end{array}$} & $\begin{array}{l}\text { 5. Shoe wheels, because it has a velocity while the } \\
\text { truck speed is zero although the mass of the truck } \\
\text { is larger than the mass of roller skates }\end{array}$ & 37 & $58.7 \%$ \\
\hline & & $\begin{array}{l}\text { 6. epic wheel, because the skates have speed so that } \\
\text { the momentum of big skates, while the truck in a } \\
\text { state of silence has no speed, so the momentum is } \\
\text { small }\end{array}$ & 17 & $27 \%$ \\
\hline & & $\begin{array}{l}\text { 7. Shoe wheels, because roller skates have a lighter } \\
\text { mass than trucks }\end{array}$ & 1 & $1.58 \%$ \\
\hline & & TOTAL STUDENTS & 63 & \\
\hline
\end{tabular}

Figure 2. Those items description to determine the students' ability to compare the momentum an object depending on mass and speed.

\section{Student Error in Problem Solving on Impulse Concept}

The items used to demonstrate the students ability to solve the problem on the concept of impulse are shown in Figure 3. The item is an impulse application. Problem indicate that a child is kicking a ball, then the child is kicking stones of the same amount with the ball. Students were asked to indicate the reasons why kicking stones, that child feel more pain than when kicking the ball. From these questions there are students who think that the force received a larger stone than the force received ball so that the impulse generated is also greater. But no student has answered the mathematically correct answer in identifying the impulse problem.

\begin{tabular}{|c|c|c|c|c|}
\hline No & Question & $\begin{array}{l}\text { The grouping of students answers } \\
\text { (total } 63 \text { students) }\end{array}$ & $\begin{array}{l}\text { The number } \\
\text { of students }\end{array}$ & Percentage \\
\hline \multirow[t]{5}{*}{8} & $\begin{array}{l}\text { A child is kicking a ball, then the child } \\
\text { is kicking a rock that is equal to the ball } \\
\text { as shown below. }\end{array}$ & $\begin{array}{l}\text { 1. Because the stone surface is more rough and the } \\
\text { frictional force on the rock is bigger, while the } \\
\text { surface on the ball is slippery (smooth) }\end{array}$ & 1 & $1.58 \%$ \\
\hline & \multirow{4}{*}{$\begin{array}{l}\text { Why when kicking a rock, the child } \\
\text { feels more pain than when kicking the } \\
\text { ball? Explain mathematically! }\end{array}$} & $\begin{array}{l}\text { 2. Because the mass of the rock is larger and has a } \\
\text { larger volume, so it takes a bigger force to kick it }\end{array}$ & 2 & $3.17 \%$ \\
\hline & & $\begin{array}{l}\text { 3. Because the kicked rock has a larger density of mass } \\
\text { than the density of the ball type so that the child } \\
\text { kicking the stone feels in pain }\end{array}$ & 4 & $6.35 \%$ \\
\hline & & $\begin{array}{l}\text { 4. Because the ball mass is lighter than the rock, the } \\
\text { ball has a flat surface and the rock has a rough } \\
\text { surface }\end{array}$ & 6 & $9.52 \%$ \\
\hline & & $\begin{array}{l}\text { 5. Because the mass of the rock is bigger than the mass } \\
\text { of the ball. Same size is not necessarily the same } \\
\text { mass }\end{array}$ & 19 & $30.2 \%$ \\
\hline
\end{tabular}


6. Because the mass of the stone is larger than the mass of the ball even though it is of equal magnitude and

Figure 3. Those items description to determine the students ability to solve the problem of impulse

\section{Student Error in Solving Problems on Collision Concept}

Used items show the student's ability to identify acceptable force in case of collision objects are presented in Figure 4. Problem indicate that an iron ball with a mass $\boldsymbol{m}$ and a beam of iron with a mass of $2 \boldsymbol{m}$ with the same speed suddenly crashed into each other. Students are required to show that when the two collide, Which objects that acquire more force and asked to give a reason. A total of 43 students have the conception that the iron ball having a larger force than the steel beams and 20 other students have the conception that the steel beams have a larger force than the iron beams. Various reasons have been shown by students as in Figure 4. From the problems no one has answered correctly that the two objects interact (give or receive a boost), then when objects collide, the force received by object 1 is equal to the force received second object (3 Newton's Laws).

\begin{tabular}{|c|c|c|c|c|}
\hline No & Question & $\begin{array}{l}\text { The grouping of students answers } \\
\text { (total } 63 \text { students) }\end{array}$ & $\begin{array}{l}\text { The number } \\
\text { of students }\end{array}$ & Percentage \\
\hline \multirow[t]{10}{*}{4} & \multirow{3}{*}{$\begin{array}{l}\text { An iron ball with mass } \mathrm{m} \text { and an iron beam } \\
\text { with a mass of } 2 \mathrm{~m} \text { with the same speed } \\
\text { suddenly crashing into each other like the } \\
\text { picture below. } \\
\qquad \mathbf{2 m}\end{array}$} & The ball & 43 & $68.2 \%$ \\
\hline & & Iron beams & 20 & $31.7 \%$ \\
\hline & & $\begin{array}{l}\text { 1. Iron beams because when the two objects collide } \\
\text { with the same speed, the steel ball style is smaller }\end{array}$ & 2 & $3.17 \%$ \\
\hline & \multirow{6}{*}{$\begin{array}{l}\text { When both collide, which objects get bigger? } \\
\text { Why? }\end{array}$} & $\begin{array}{l}\text { 2. The iron ball because the area of the iron ball cross } \\
\text { section is smaller than the iron beam }\end{array}$ & 3 & $4.76 \%$ \\
\hline & & $\begin{array}{l}\text { 3. Iron beam because it has a mass larger than the iron } \\
\text { ball so it has a larger style }\end{array}$ & 7 & $11.1 \%$ \\
\hline & & $\begin{array}{l}\text { 4. The iron ball, whose mass } \mathrm{m} \text { is due to the gravity of } \\
\text { an object } 2 \mathrm{~m} \text { larger and the iron bar will retain its } \\
\text { position }\end{array}$ & 8 & $12.7 \%$ \\
\hline & & $\begin{array}{l}\text { 5. } \\
\text { Beams, because the beam has a larger cross- } \\
\text { sectional area than an iron ball, so when both collide } \\
\text { objects that will get a larger style is the beam }\end{array}$ & 11 & $17.5 \%$ \\
\hline & & $\begin{array}{l}\text { 6. Iron ball with mass m. When the two objects collide } \\
\text { then the iron balls will be pushed to the left as it gets } \\
\text { the force force of the iron block with a mass of } 2 \mathrm{~m}\end{array}$ & 14 & $22.2 \%$ \\
\hline & & $\begin{array}{l}\text { 7. An iron ball because its mass is smaller than an iron } \\
\text { block }\end{array}$ & 18 & $28.6 \%$ \\
\hline & & TOTAL STUDENTS & 63 & \\
\hline
\end{tabular}

Figure 4. Those items description to determine the ability of students in solving problems in the concept of collision 


\section{Isomorphic Product Results from some Conception Students Description}

Category of student answers:

\begin{tabular}{|c|c|}
\hline $\begin{array}{l}\text { Category } \\
1\end{array}$ & $\begin{array}{l}\text { Students think that objects that have larger masses will get a greater force } \\
\text { when they collide. }\end{array}$ \\
\hline $\begin{array}{l}\text { Category } \\
2\end{array}$ & $\begin{array}{l}\text { Students think that objects that have larger cross-sectional areas have a } \\
\text { greater force when they collide. }\end{array}$ \\
\hline $\begin{array}{l}\text { Category } \\
3\end{array}$ & $\begin{array}{l}\text { Students think that something we all roll will get a larger force in } \\
\text { collisions. }\end{array}$ \\
\hline $\begin{array}{l}\text { Category } \\
4\end{array}$ & $\begin{array}{l}\text { Students think that when two objects interact (give or receive } \\
\text { encouragement) then when the object collides, the force received by object } \\
1 \text { is the same as the force received by the object } 2 \text { ( } 3 \text { Newton's Laws). }\end{array}$ \\
\hline
\end{tabular}

Isomorphic Problem :

1. An iron ball with a mass $m$ and a beam of iron with a mass of $2 m$ with the same speed suddenly collide like the image below.
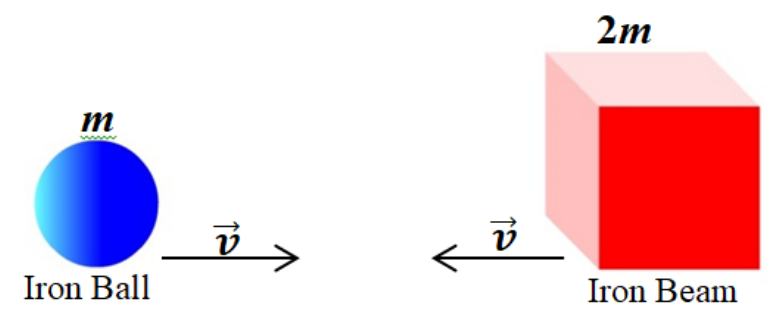

When they collide, Which objects that get larger force?

a. Iron beams, because the mass is larger than the iron ball, so when the two collide that gets bigger style is the iron beam. (category 1)

b. Iron beam, the area of the cross section of the iron beam is wider than the iron ball, so when both collide the iron ball will bounce because the iron beam has a bigger style. (category 2)

c. An iron ball, because the ball mass of iron is lighter than an iron block and the surface of an iron ball is easier to roll than a block of iron. So when both collide which gets bigger style is iron ball. (category 3)

d. Equally great, because when two objects interact (give or receive a boost) the received force of the iron beam is the same as the received force of the iron ball. (category 4)

\section{The Result of The Analysis Item}

The results of the analysis item multiple-choice diagnostic test instruments isomorphic consist of reliability, level of difficulty, and different power items. Test reliability analysis is used to determine the extent to which test reliability provides a fixed result when multiple tests are performed. Reliability is the permanence test if done the same subject. The determination can be seen from the results alignment. Based on the analysis using Cronbach Alpha formula, obtained reliability of 0.53 . The diagnostic 
test instrument in this study has the reliability in the medium criterion. The result of the difficulty analysis is used to indicate the difficulty level of each item. The results of the analysis of different power items used to determine the extent to which these problems can distinguish the ability of test takers, intelligent and less intelligent. The upper and lower group divisions use the upper $27 \%$ and $27 \%$ of the lower groups.

\section{Instrument Test Results}

The isomorphic diagnostic test was conducted on XI MIA 4 MAN Tlogo Blitar and $\mathrm{X}$ class MIA U1 MAN 1 Tulungagung. After testing diagnostic instrument, followed by a description of the problem of testing the same students. The trial results are described in the chart instrument validity test which matches the two problems have the same consistent conception of a percentage greater than the chart matches on a consistent three conceptions about the same. In the first indicators, charts consistently match two problems at the same conception has a percentage of $60.6 \%$, while the threequestion compatibility chart consistently on the same conception has a percentage of $8.2 \%$. On the second indicator, chart consistently match two questions on the same conception had a percentage of $63.9 \%$, while the three-question compatibility chart consistently on the same conception has a percentage of $3.3 \%$. In indicator 3 , between the two graphs shows the largest difference among the four other indicators. Graph consistently match two questions on the same conception had a percentage of $78.7 \%$, while the three-question compatibility chart consistently on the same conception has a percentage of $1.6 \%$.

On the indicator 4 , graphs consistently match two questions on the same conception had a percentage of $65.6 \%$, while the three-question compatibility chart consistently on the same conception has a percentage of $9.8 \%$. Meanwhile, on indicator 5 the match graph of two consistent problems on the same conception has a percentage of $50.8 \%$ whereas the match graph of three consistent problems on the same conception has a percentage of $3.3 \%$. Based on the results the percentage of all indicators, we can conclude that it is better researchers took two questions consistent compatibility chart on the same conception compared to three consistent conception about the same on each indicator. 


\section{Results of Student Misconception Analysis Based on Isomorphic Test Instrument}

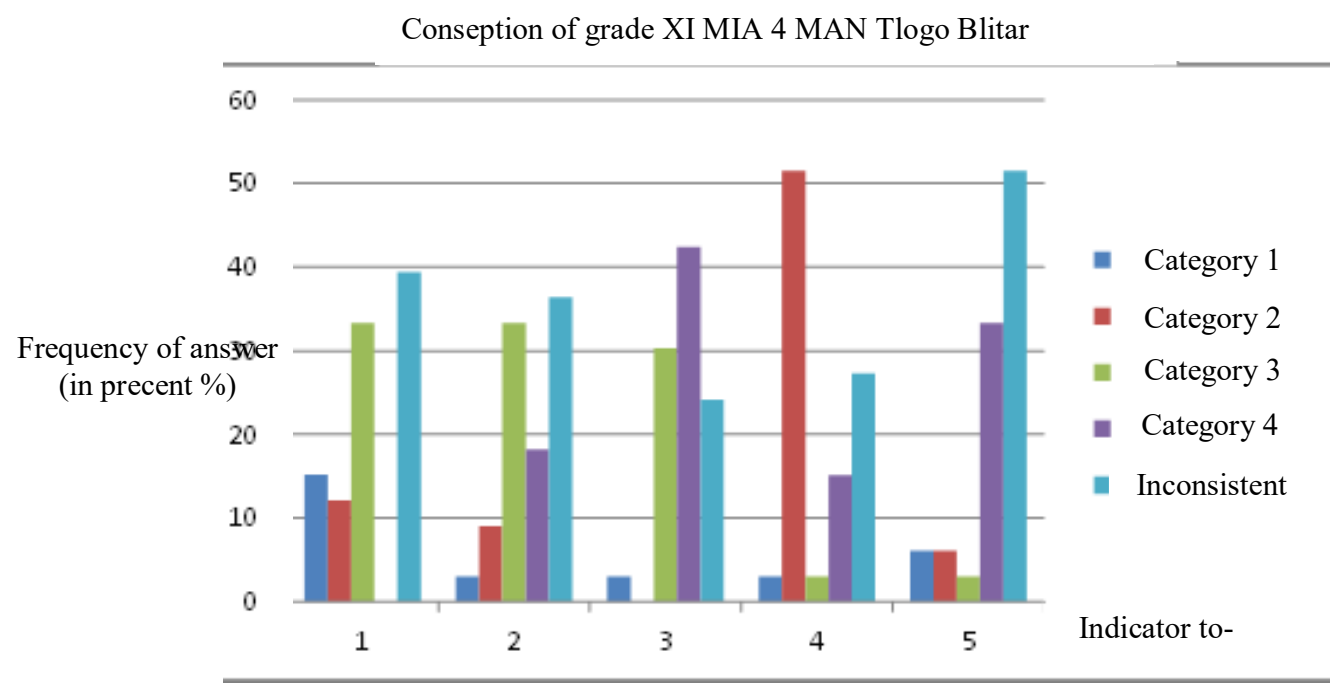

In general there are still many students of grade XI MIA 4 who have misconception of momentum and impulse material. This is indicated by the bar graph in Figure 4.3 derived from the student's answer. In the isomorphic test instrument provided. Based on the graph below shows that student misconceptions vary across the five categories for all indicators. There are some interesting things about the conception of students of grade XI MIA 4 MAN Tlogo Blitar based on the results of isomorphic test instrument analysis. In the first indicator none of the students who have the conception level 4. In addition, the indicators 1, 2, and 5 are still many students who are not consistent (weak mastery of concepts). In indicator 4 most have the conception of category 2 . But on indicator 3 many students have a true conception.

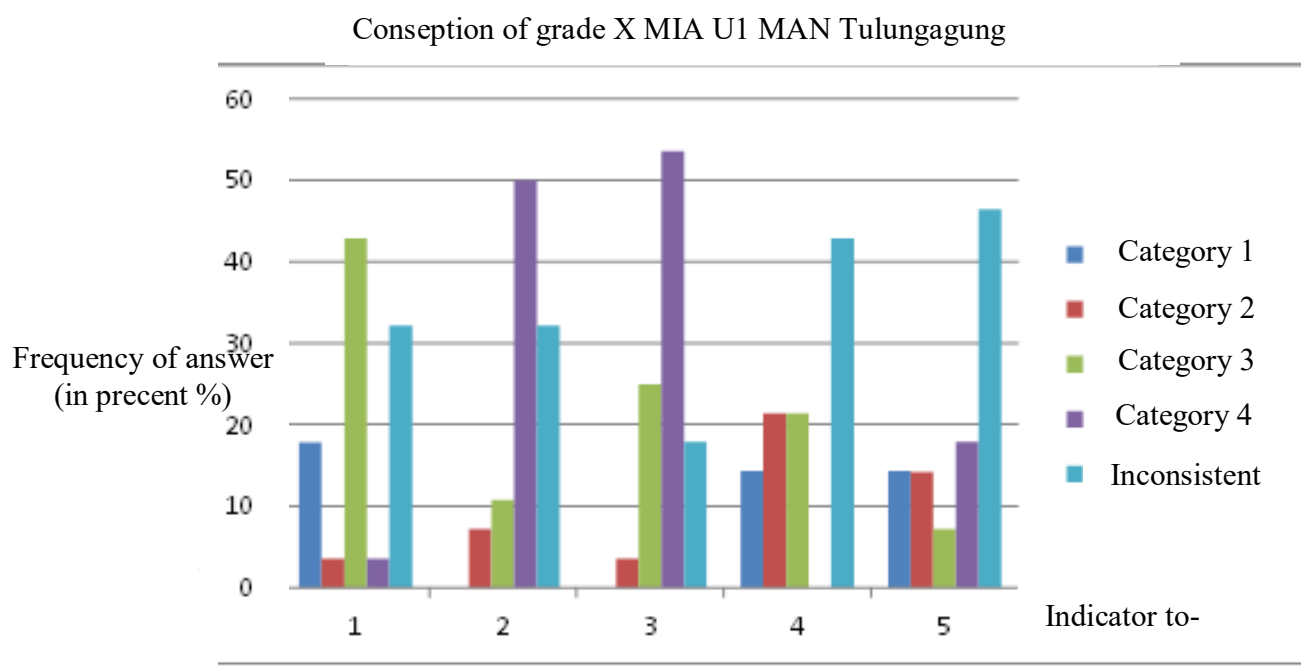

In general there are many students of grade X MIA U1 MAN 1 Tulungagung who experienced misconception. In indicator 1 most students have a conception in category 3 , unlike in indicators 2 and 3 that most students have a true conception. In indicators 4 
and 5 most students of grade X MIA U1 MAN 1 Tulungagung not consistent in answering.

\section{Product Review and Sugesstion}

\section{Product Review}

The final product of development in this research is an isomorphic diagnostic instrument on momentum and impulse material consisting of 15 questions covering 5 indicators. The developed product has been revised with content validation results conducted by expert lecturers and two physics teachers. The results of the validation score analysis indicate that the resulting product has been declared feasible and able to identify student misconceptions on moemntum and impulse materials. Product in terms of item is good and feasible because each formulation is able to collect the forms of the wrong conception of the students. Product in terms of choice of answers can be said to be good because it is able to make students think to answer each item. Product in terms of the ability to identify misconception is good and feasible with the results show validation validation by content validator. However, the resulting product still needs to be revised on certain numbers that are not too significant. The accuracy of the product in terms of the suitability of the item of description has reached conformity with the average on each indicator above $50 \%$. These results were obtained from the sum of fourth grade students MIA Tlogo MAN Blitar and class $\mathrm{X}$ MIA U1 MAN 1 Tulungagung. One reason for the not so high percentage of the suitability of multiple isomorphic choice diagnostic instruments with true-tested descriptions is the inconsistent percentage of students contributing substantially.

The isomorphic double choice diagnostic test instrument has the following specifications: (1) The isomorphic diagnostic instrument consists of three equivalent items in one indicator on the matter of momentum and impulse, (2) multiple choice questions with four answer options, (3) diagnostic instruments isomorphic to declare the student has the right conceptions, misconceptions (misconceptions) and inconsistent based on at least two of the three-point answer multiple choice questions consistently. The developed diagnostic tools have advantages and disadvantages. The advantages in this isomorphic diagnostic instrument are (1) each item developed has meaning because the choice of answers used is captured from student conceptions, (2) item on one indicator is able to detect students who really have correct conception, weak in the mastery of concepts and misconceptions. The lack of developed instruments is (1) does not provide opportunities for students to deliver answers beyond the answers provided, (2) identification of student conditions through their answers using this instrument is still done manually so it is less efficient for teachers. 


\section{Suggestion of further utilization and development}

Based on the results of the analysis on students answers indicates that the number of students experiencing misconceptions is still quite large. Though the student has obtained the learning material. This is expected to be of concern in the world of education and the need for further evaluation of the implementation of learning in the classroom. Learning in the classroom needs to be improvements that can reduce students who are in a state experiencing misconceptions and no conception. It is necessary to think about appropriate handling of such students, so that they can have the correct conception according to the scientific viewpoint. This isomorphic test instrument needs to be continuously developed, both for other physics materials. This is because the isomorphic test instrument is not only valid but can also diagnose student misconception quickly and accurately. In order to accommodate many conceptions of students it is better to answer more than four answer options. These additions, will increase the level of suitability item multiple choice diagnostic isomorphic with the problem description.

\section{References}

Abdurrahman, M. 2012. Anak Berkesulitan Belajar. Jakarta: Rineka Cipta.

Al-Rubayea. 1996. An Analysis of Saudi Arabian High School Students' Misconceptions about Physics Concepts. Disertasi tidak diterbitkan. Manhattan: Department of Curiculum and Instruction College of Education of Kansas State University.

Bonnett, George. 2006. Momentum: Myths and Misconceptions. International Journal of Science Education, (Online), (https://store.iptm.org/products/momentummyths-and-misconceptions) access at 15 Februari 2017.

Bostan, Ayberk. 2013. Comparison of High School Students Ideas about

Momentum and Impulse Conceptions Before and After Instruction. Social and Behavioral Sciences, (Online), 116(2014): 3771-3775 (http://www.sciencedirect.com/science/article/pii/S1877042814008568) access at 6 Februari 2017.

Brooks, Val. 2002. Assessment In Secondary School: The New Teacher's Guide To Monitoring, Assessment, Recording, Reporting, and Accountability. Philadelphia: Open University Press.

HM, Jogiyanto. 2013. Pedoman Survei Kuisioner: pengembangan kuisioner, Mengatasi bias, dan Meningkatkan Respon. Yogyakarta: BPFE-Yogyakarta.

Irons, Alastair. 2008. Enhancing Learning Through Formative Assessment and Feedback. New York: Routledge.

Karim, Saeful.2015. Diagnosis Kesulitan Belajar Mahasiswa Dalam Memahami Konsep Momentum. Jurnal Penelitian \& Pengembangan Pendidikan Fisika. Volume 1, Nomor 1, 2015. (Online), (http://jpppf.fisika-unj.ac.id), access at 20 Februari 2017. 
Kurnia, Diyan. 2016. Kesalahan Siswa SMA dalam Memecahkan Masalah MomentumImpuls. Pros Semnas Pendidikan IPA Pascasarjana UM. Vol.1(2016): 174183.

Lin, Shih \& Chandralekha Singh. 2011. Using Isomorphic Problems To Learn Introductory Physics. Physical Review Special Topics - Physics Education $\begin{array}{llll}\text { Research, } & \text { (Online), } & 7 & \text { (2): }\end{array}$ (http://journals.aps.org/prper/abstract/10.1103/PhysRevSTPER.7.020104), access at 10 November 2016.

Lin, Shih \& Chandralekha Singh. 2013. Using An Isomorphic Problem Pair To Learn Introductory Physics: Transferring From A Two-Step Problem To A ThreeStep Problem. Physical Review Special Topics - Physics Education Research, (Online), 9 $1-21$ (http://journals.aps.org/prper/abstract/10.1103/PhysRevSTPER.9.020114), access at 10 November 2016.

Lusiana, Naning. 2016. Analisis Miskonsepsi Siswa Pokok Bahasan Momentum Dan Impuls Di Kelas Xii Ipa.4 Sma Negeri 4 Lubuklinggau Tahun Pelajaran 2015/2016. Jurnal Penelitian Pendidikan Fisika, (Online). (http://mahasiswa.mipastkipllg.com/repository/JURNAL+\%20naning\%20lusia na.pdf), access at 15 Februari 2017.

N. Remziye. 2013. Momentum Concept in the Process of Knowledge Construction. International Journal of Science Education, (Online), 13(3): 1897-1901, (www.edam.com.tr/estp), access at 15 Februari 2017.

Peraturan Menteri Pendidikan dan Kebudayaan Republik Indonesia Nomor 104 Tahun 2014 tentang Penilaian Hasil Belajar Oleh Pendidik pada Pendidikan Dasar dan Pendidikan Menengah. Menteri Pendidikan dan Kebudayaan Republik Indonesia.

Pusat Penilaian Pendidikan tentang Laporan Hasil ujian Nasional Tahun 2014. Kementerian Pendidikan dan Kebudayaan: Badan Penelitian dan Pengembangan.

Singh, Chandralekha. 2008. Assessing Student Expertise In Introductory Physics With Isomorphic Problems II Effect Of Some Potential Factors On Problem Solving And Transfer.

Surapranata, Sumarna. 2005. Analisis, Validitas, Reliabilitas, dan Interpretasi Data Hasil Tes. Bandung: Remaja Rosdakarya.

Uno, Hamzah B.. 2012. Assessment Pembelajaran. Jakarta: Bumi Aksara. 